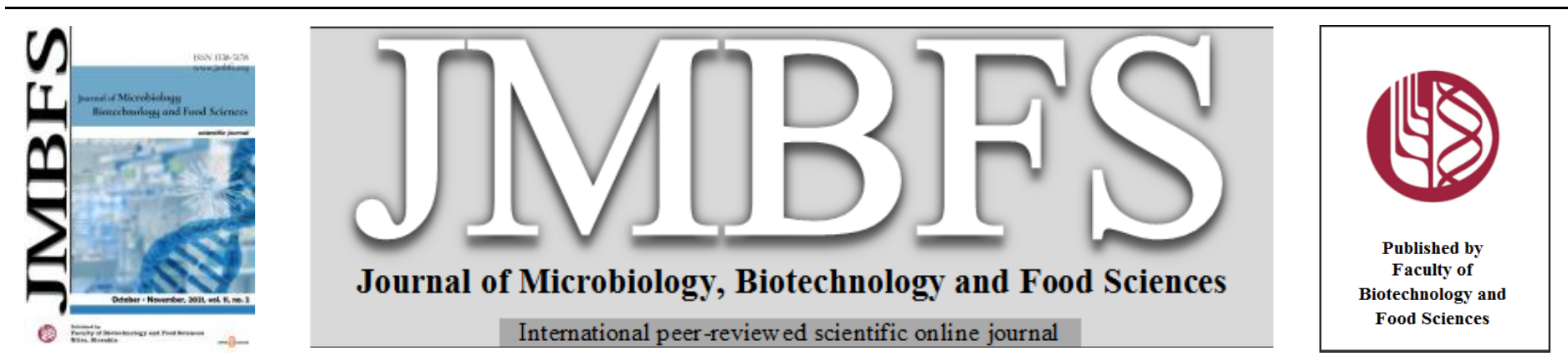

\title{
HAIR REMOVAL POTENTIAL OF KERATINASE PRODUCED BY BACILLUS SPECIES ISOLATED FROM FEATHER WASTE
}

\author{
Michael Dada*, Sherifah Wakil
}

Address(es): Dr. Michael Dada,

University of Ibadan, Faculty of Science, Department Microbiology, 200284, Ibadan, Oyo, phone number: +2348037832483 .

*Corresponding author: dadamaik1@yahoo.com

https://doi.org/10.15414/jmbfs.2113

\section{ARTICLE INFO}

Received 7. 4. 2020

Revised 18. 4. 2021

Accepted 23. 4. 2021

Published 1. 10. 2021

Regular article open $\odot$ access

\begin{abstract}
Keratins are tough, fibrous proteins found as the major protein component in hair. Chemical hair removal is harsh and results in severe toxicity and pollution, hence, a need for a non-chemical enzymatic hair removal process. The aim of this study is to characterise keratinase from isolated keratin-degrading Bacillus licheniformis-K51, Bacillus subtilis-K50 and Bacillus sp.-K53 and investigate its potential in hair removal. The collagenolytic ability of keratin-degrading keratinases obtained from Bacillus licheniformis-K51, Bacillus subtilis-K50 and Bacillus sp.-K53 was determined using standard methods. The depilatory potential of keratinase (directly and as part of the constituent of formulated depilatory cream) was determined in vitro on goat skin and in vivo on Wistar rat. Purified keratinases from Bacillus licheniformis-K51 (EZYKer-51), Bacillus subtilis-K50 (EZYKer-50) and Bacillus sp.-K53 (EZYKer-53) did not show significant collagenolytic activities. In vitro treatment of goat skin with EZYKer-51 showed total hair removal within 24 hours and partial hair removal with EZYKer-50 and EZYKer-53. The formulated depilatory cream containing EZYKer-51 showed highest keratinolytic activity $(22.20 \pm 0.63 \mathrm{U} / \mathrm{mL})$ followed by EZYKer-50 $(20.52 \pm 0.46 \mathrm{U} / \mathrm{mL})$ and EZYKer-53 (17.06 $\pm 0.81 \mathrm{U} / \mathrm{mL})$. In vivo depilatory action using formulated cream took $40 \mathrm{~min}$, while that of commercial cream was achieved within $20 \mathrm{~min}$.

Keratinase from Bacillus licheniformis-K51 exhibited complete hair-removal function which makes it potentially suitable in industrial processes involving removal of hair.
\end{abstract}

Keywords: Keratin-degrading bacteria, Bacillus keratinase, Keratin, Feather waste, Hair-removal

\section{INTRODUCTION}

Enzymes are macromolecular biological catalysts (Stryer, 2002). Their choice over chemicals in the improvement of efficiency and reduction of cost in different industrial processes and systems has been in process for a long time (Jaouadi et al., 2011). Proteases have a wide distribution in nature and are particularly important in their ability to hydrolyse peptide bonds in aqueous environments (Jaouadi et al., 2011). Keratinase are a group of proteases with a wide temperature and $\mathrm{pH}$ range that allow complete degradation of complex and recalcitrant proteins such a keratin (Vidmar and Vodovnik 2018). Keratins is resistant to digestion by plant and animal enzymes and many common proteases from microorganisms. As a result of intermolecular disulfide linkages, keratins are insoluble in water, weak acids and alkalis. Unlike other natural polymers such as starch, collagen and chitosan, keratin possesses a complex three-dimensional structure that requires the use of harsh chemical conditions for their dissolution (Feroz et al., 2020).

Hair is a filamentous biomaterial that consists mainly of proteins in particular keratin (Yang et al., 2014). Hair has about 300 identified proteins (Lee et al. 2006). The proteins having the largest concentration in hair are those containing a very high percentage by weight of sulfur in their structure. They aggregate in the entire hair fibre or at specific locations in the fibre (Rogers, 2004). Such proteins include keratins and the Keratin Associated Proteins (KAPs). Keratins are stable, water-insoluble structural fibrous proteins found in stratum corneum and protective tissues such as hair, nail, feather, wool and horns. They play a crucial role in the formation of tough hair shaft through a cross linked network (Yutaka and Masaaki, 2015). The strength of keratin is derived from tightly packed alpha helical and beta sheet configurations which they possess. They also contain a high degree of disulfide bonding which makes them rigid and tough (Navone and Speight, 2018). Biological degradation of keratin can be effectively carried out by keratinases or keratinolytic enzymes which are a class of extracellular proteolytic enzymes. They are inducible (Munawar, 2012), acquiring the capacity to breakdown highly rigid keratin substrates. Keratinases are nonspecific serine-type proteases that are able to cleave non-terminal peptide bonds. They have keratin-degradation mechanism that remains unclear (Kang et al., 2019). Microbial keratinase production takes place only in the presence of substrates that contain keratins. This means that the presence of keratin activates the release of keratinase, keratin thus playing the role of an inducer (Munawar, 2012).

Chemical hair-removal processes require the use of harsh chemicals with strong reducing properties which could have an adverse effect on the skin when applied for long (Qurat-Ul-Ain et al., 2013). Untreated waste water, which contains high salt and process chemical content is one of the major concerns in tanneries since most of the steps in tannery are performed in water. Major stages in tannery which include liming and hair burning introduce intense displeasing odour, severe toxicity and pollution (Ali et al., 2018). Because of this, a need for a nonchemical alternative such as an enzymatic hair removal process with the use of keratinase is proposed. This research is therefore focused on purifying and characterising keratinase produced by Bacillus species isolated from poultry feather waste, and to investigate its potential in hair removal.

\section{MATERIAL AND METHODS}

\section{Material}

All chemicals used were of analytical grade obtained from Sigma-Aldrich (United States). Keratinases; EZYKer-51, EZYKer-50 and EZYKer-53 from keratin degrading Bacillus licheniformis-K51, Bacillus subtilis-K50 and Bacillus sp.-K53 respectively were obtained from a previous work carried out at the Industrial Microbiology of the University of Ibadan (Dada and Wakil, 2020).

\section{Collagenolytic Activity of Purified Keratinase}

Collagenolytic activity of purified keratinase enzyme was carried out by separately preparing $0.2 \mathrm{mg}, 0.4 \mathrm{mg}, 0.8 \mathrm{mg}$ and $1.0 \mathrm{mg}$ of collagen in 0.2 Tris $\mathrm{HCl}$ buffer ( $\mathrm{pH} 7.4$ ) and reacting with $0.1 \mathrm{~mL}$ keratinase solution at $38{ }^{\circ} \mathrm{C}$ for 10 min. After which centrifugation was done at a speed of $1450 \mathrm{xg}$ for $30 \mathrm{~min}$, the supernatant was obtained and the absorbance was taken at wave length of $440 \mathrm{~nm}$ against a control which was prepared by the incubation of the denatured enzyme (by boiling) with each of the collagen solutions. One unit (U/mg) of collagenase activity is measured as the amount of the enzyme that is required to produce a change in absorbance which is equal to 0.1 in $10 \mathrm{~min}$ (Leighton et al., 1973) 


\section{Depilatory action of Keratinase on goat skin}

The depilatory action of keratinase on goat skin was carried out by a modified method of Jaouadi et al. (2011). Fresh goat skins where cut to small sizes of about 12- 20 square centimeters in area and placed in Petri-dishes containing 20 $\mathrm{mL}$ of keratinases. Hair removing capacity of the enzyme was observed by rubbing a spatula over the skin to pull out the hair at intervals of $1 \mathrm{~h}$.

\section{Formulation of Depilatory Cream}

The formulation of depilatory cream was carried out by a modified method of Elumalai et al. (2013). The following components are required in the making of depilatory cream. Component A which is made up of Emulsifier: TWEEN80 $(0.02 \%)$, thickener: Carbopol $(0.5 \%)$, Thiourea $(0.5 \%)$ and emollient: Liquid paraffin $(0.5 \%)$. Component $\mathrm{B}$ which is made up of Water and chelating agent Ethylenediaminetetraacetic acid (EDTA) $(0.45 \%)$; component $\mathrm{C}$ which is made up of the base; $\mathrm{CaOH}(0.5 \%)$ neutralizer; and Calcium Carbonate $(6 \%)$ and Component D; Keratinase (8\%).

Components B and A are heated separately to $75{ }^{\circ} \mathrm{C}$ and mixed rapidly for $5 \mathrm{~min}$. The mixing continued at a reduced rate while mixtures $\mathrm{A}$ and $\mathrm{B}$ cools to about 35 ${ }^{\circ} \mathrm{C}$ after which the component of $\mathrm{C}$ is added and mixed rapidly for another $5 \mathrm{~min}$. After complete cooling, Component $\mathrm{D}$ is added and mixed for about $10 \mathrm{~min}$ and stored in the refrigerator

\section{Effect of depilatory cream components on keratinase activity of enzyme}

The effect of the individual depilatory cream components on the keratinase activity of both crude and purified enzyme was carried out by a modified method of Jaouadi et al. (2011) by incubating 8\% Keratinase with the keratin preparation containing, separately, the following depilatory cream components; Carbopol $(0.5 \%), \mathrm{CaOH}(0.5 \%)$, Calcium Carbonate $(6 \%)$, Thiourea $(5 \%)$, TWEEN $80(0.02 \%)$, Liquid Paraffin $(0.5 \%)$, EDTA $(0.45 \%)$, and Fragrance $(0.6 \%)$, then assayed for enzyme activity.

\section{Preparation of soluble keratin}

Keratinase activity was assayed using soluble keratin substrate $(0.5 \% \mathrm{~g} / \mathrm{v})$ as substrate and was prepared by the modified method (Wawrzkiewiez et al. 1987). Ten grams of white chicken feathers was heated in $500 \mathrm{~mL}$ of $50 \%$ dimethyl sulfoxide (DMSO) at a temperature of $100{ }^{\circ} \mathrm{C}$ for two hours. The resulting soluble keratin was obtained by precipitation with $1 \mathrm{~L}$ acetone at freezing temperature for $6 \mathrm{~h}$. the precipitate was obtained by undergoing centrifugation at $10,000 \mathrm{x} \mathrm{g}$ for $10 \mathrm{~min}$. The resulting precipitate was washed three times with water and dried at $70^{\circ} \mathrm{C}$ for $24 \mathrm{~h}$ in an oven dryer. One gram of the obtained precipitate was dissolved in $20 \mathrm{~mL}$ of $0.05 \mathrm{M} \mathrm{NaOH}$. Using $0.1 \mathrm{M}$ Tris and $0.1 \mathrm{M} \mathrm{HCl}$ the $\mathrm{pH}$ was adjusted and stabilized at 8.0 and the solution was made up to $200 \mathrm{~mL}$ with the same buffer.

\section{Determination of keratinolytic activity}

The keratinolytic activity of the bacterial enzyme was assayed as follows: One milliliter of the purified enzyme which has been properly diluted in Tris-HC buffer $(0.05 \mathrm{M} \mathrm{pH} 8.0)$ was incubated with $1 \mathrm{~mL}$ keratin solution at a temperature of $50{ }^{\circ} \mathrm{C}$ for ten min in a water bath. The reaction was terminated by the addition of $2.0 \mathrm{~mL}$ of $0.4 \mathrm{M}$ Trichloroacetic acid (TCA). After centrifugation at speed of $1450 \mathrm{xg}$ for $30 \mathrm{~min}$, the absorbance of the supernatant was determined at a wave length of $280 \mathrm{~nm}$ against a control which was prepared by incubating the enzyme solution with $2.0 \mathrm{~mL}$ TCA without the addition of keratin solution.

One unit $(\mathrm{U} / \mathrm{mL})$ of keratinolytic activity was defined as an increase in corrected absorbance of $280 \mathrm{~nm}\left(\mathrm{~A}_{280}\right)$ (Gradisar et al., 2000) with the control for 0.01 per minute and calculated by the following equation:

$$
U=\frac{4 n \times A_{280}}{(0.01 \times 10)}
$$

Where; $\mathrm{n}=$ dilution rate, $4=$ final reaction volume $(4 \mathrm{~mL}), 10=$ incubation time (min)

\section{Effect of combined depilatory cream component on keratinase activity of enzyme}

The effect of the combined depilatory cream components on the keratinase activity of the both the crude and purified enzymes were carried out by a modified method Jaouadi et al. (2011). The Keratinase was incubated with the keratin preparation containing the combined depilatory cream components; Carbopol $(0.5 \%), \mathrm{CaOH}(0.5 \%)$, Calcium Carbonate $(6 \%)$, Thiourea $(5 \%)$, TWEEN $80(0.02 \%)$, Liquid Paraffin $(0.5 \%)$, EDTA $(0.45 \%)$, and Fragrance $(0.6 \%)$, then assayed for enzyme activity.

\section{Depilatory action of Keratinase on goat skin}

Fresh goat skins where cut to small sizes of about 12- 20 square centimeters in area and placed in Petri-dishes containing $20 \mathrm{~mL}$ of Keratinases. Hair removing capacity of the enzyme was observed by rubbing a spatula over the skin to pull out the hair at intervals of $1 \mathrm{~h}$.

\section{Depilatory action of keratinase on Wistar rat}

The formulated depilatory cream composed of; Carbopol, $\mathrm{CaOH}$, Calcium Carbonate, Thiourea, TWEEN 80 , Liquid Paraffin, EDTA, Fragrance and Keratinase was applied generously on the dorsal surface of Wistar rat and the hair removal by cream was determined by the ease with which the hair of the rat is removed when pulled out over intervals of $15 \mathrm{~min}$ for $2 \mathrm{~h}$.

\section{Statistical analysis}

The data obtained from this experiment were analyzed by one way analysis of variance (ANOVA) and means of differences among treatment were examined using Duncan's multiple rage test at $\mathrm{p}<0.05$

\section{RESULTS}

\section{Collagenolytic Activity of Purified Keratinases}

The result of the collagenolytic activity of the purified EZYKer-50, EZYKer-51 and EZYKer-53 is presented on Table 1. The table shows that all the three enzymes gave no observable collagenolytic activity at collagen concentration of $0.2 \mathrm{mg} / \mathrm{mL}$ and no significant increase $(\mathrm{P}<0.05)$ in collagenolytic activity was observed as the collagen concentration was increased from $0.2 \mathrm{mg} / \mathrm{mL}$ to 1 $\mathrm{mg} / \mathrm{mL}$. EZYKer-53 had highest activity at all tested concentrations which was not significantly different $(\mathrm{P}<0.05)$ from other enzymes and no activity observed for EZYKer-51 at all concentrations

$\underline{\text { Table } 1 \text { Collagenolytic Activity of Purified Keratinases }}$

\begin{tabular}{lcccc}
\multicolumn{3}{l}{ Table 1 Collagenolytic Activity of Purified Keratinases } \\
& & \multicolumn{4}{c}{$\begin{array}{c}\text { Collagen Concentration } \\
(\mathbf{m g} / \mathbf{m L}) / \text { Collagenolytic Activity }\end{array}$} \\
\hline Enzyme Code & $\mathbf{0 . 2}$ & $\mathbf{0 . 4}$ & $\mathbf{0 . 8}$ & $\mathbf{1 . 0}$ \\
\hline EZYKer-50 & $0.00 \pm 0.00^{\mathrm{a}}$ & $0.01 \pm 0.00^{\mathrm{a}}$ & $0.01 \pm 0.00^{\mathrm{a}}$ & $0.00 \pm 0.00^{\mathrm{a}}$ \\
EZYKer-51 & $0.00 \pm 0.00^{\mathrm{a}}$ & $0.00 \pm 0.00^{\mathrm{a}}$ & $0.00 \pm 0.00^{\mathrm{a}}$ & $0.00 \pm 0.00^{\mathrm{a}}$ \\
EZYKer-53 & $0.00 \pm 0.00^{\mathrm{a}}$ & $0.03 \pm 0.01^{\mathrm{a}}$ & $0.05 \pm 0.01^{\mathrm{a}}$ & $0.03 \pm 0.01^{\mathrm{a}}$ \\
\hline
\end{tabular}

Values are in means \pm standard deviation; at $95 \%$ confidence level, means with different / similar superscripts along the same row are significantly different / not significantly different from one another

\section{Effect of Depilatory Ingredients on Keratinase Activity of Purified and Crude Keratinases}

The result for the effect of depilatory ingredients on keratinase activity of purified and crude keratinases is shown in Table 2. The result showed that EZYKer-51 gave a significantly higher enzyme activity $(\mathrm{P}<0.05)$ in the presence of the depilatory ingredients for both the crude and purified forms of the enzyme compared with the activities of enzymes EZYKer-50 and EZYKer-53 except in the presence of $0.5 \% \mathrm{CaOH}$ and $0.02 \%$ TWEEN 80 where EZYKer-50 showed a significantly $(\mathrm{P}<0.05)$ higher activity than the others. EZYKer-53 showed lowest keratinase activities with all the depilatory ingredients for both crude and purified forms of the enzymes compared to EZYKer-50 and EZYKer51 except in the presence of $6 \%$ Calcium carbonate where the crude form of the EZYKer-50 showed lowest activity.

From the table, the purified form of EZYKer-50 showed significantly higher $(\mathrm{P}<0.05)$ enzyme activities than the crude form in the presence of the depilatory ingredients except in the presence of $0.5 \% \mathrm{CaOH}$, where enzyme activity of the crude form of the enzyme was significantly higher $(\mathrm{P}<0.05)$ than the purified form, and $0.02 \%$ TWEEN 80 where the observed difference in activity was not significant $(\mathrm{P}<0.05)$. The purified form of EZYKer-51 showed significantly higher $(\mathrm{P}<0.05)$ keratinolytic activity in the presence of the depilatory ingredients except in the presence of $0.5 \%$ Carbopol, where enzyme activity of the crude form of the enzyme was significantly higher $(\mathrm{P}<0.05)$ than the purified form, and $0.45 \%$ EDTA where the observed difference in activity was not significant $(\mathrm{P}<0.05)$. For EZYKer-53, except for $0.5 \%$ Carbopol and $6 \%$ Calcium carbonate, which gave a significantly higher keratinase activity with the crude enzyme than with the purified enzyme, the purified form of the enzyme gave significantly higher $(\mathrm{P}<0.05)$ enzyme activities than the crude form of the enzyme. The observed difference in the enzyme activities in the presence of $0.5 \%$ liquid paraffin and $0.45 \%$ EDTA was not significant $(\mathrm{P}<0.05)$.

The result also shows that EZYKer-50, EZYKer-51 and EZYKer-53 showed lower enzyme activities in the presence of depilatory ingredients than with the control for both crude and purified enzymes. Of the eight ingredients, $0.45 \%$ EDTA gave lowest keratinase activities for both crude and purified forms of the three enzymes. Highest enzyme activities of $18.51 \pm 0.46 \mathrm{U} / \mathrm{mL}, 24.52 \pm 0.06$ 
$\mathrm{U} / \mathrm{mL}$ and $17.25 \pm 0.04 \mathrm{U} / \mathrm{mL}$ were observed at $5 \%$ Thiourea only for the purified forms of EZYKer-50, EZYKer-51 and EZYKer-53 respectively, while for the crude forms of the enzymes, highest activities of $17.31 \pm 0.53 \mathrm{U} / \mathrm{mL}, 20.82 \pm 0.87$ $\mathrm{U} / \mathrm{mL}$ and $15.51 \pm 1.21 \mathrm{U} / \mathrm{mL}$ were respectively observed in the presence of $0.5 \%$ $\mathrm{CaOH}, 6 \%$ Calcium carbonate and $0.5 \%$ liquid paraffin.

\section{Combined Effect of All Depilatory Cream Ingredients on Keratinase Activity}

The effect of combining all the depilatory cream components on the keratinase activity of both purified and crude EZYKer-50, EZYKer-51 and EZYKer-53 enzymes is shown in Figure 1. Keratinase activity for both purified and crude enzymes was lower on addition of combined depilatory cream ingredients than in the control (without any of the depilatory cream component). The purified forms of the three enzymes gave higher keratinase activity than the crude forms. EZYKer-51 gave higher activity than enzymes EZYKer-50 and EZYKer-53 both in purified $(22.204 \mathrm{U} / \mathrm{mL})$ and Crude $(19.217 \mathrm{U} / \mathrm{mL})$ forms, followed by EZYKer-50 at activities of $20.518 \mathrm{U} / \mathrm{mL}$ and $15.388 \mathrm{U} / \mathrm{mL}$ for purified and crude forms respectively. Least enzyme activity of $17.057 \mathrm{U} / \mathrm{mL}$ was observed in EZYKer-53 for purified and $13.198 \mathrm{U} / \mathrm{mL}$ for the crude form.

\section{Dehairing Function of Keratinases}

Dehairing function of EZYKer-50, EZYKer-51 and EZYKer-53 with goat hair is shown on plate 1. Partial hair removal was observed at $1 \mathrm{~h}$ of application of EZYKer-51 and EZYKer-53 except for EZYKer-50 which did not show any hair removal. Complete hair removal was observed after $2 \mathrm{~h}$ for EZYKer-51 while nearly complete hair removal was shown on goat skin treated with EZYKer-53 and EZYKer-50 respectively up till $24 \mathrm{~h}$ of treatment.

Dehairing Function of Formulated Depilatory Cream (DEPIKER 51) on Wistar rat

The in vivo application of the formulated depilatory cream (DEPIKER 51) on Wistar rat is as shown on plate 2 . On plate $2 \mathrm{~A}$, the hair of the untreated rat remains intact. After 20 min of application of DEPIKER 51 on the Wistar rat, hair from the rat comes off gradually from the point of application of DEPIKER 51. After $40 \mathrm{~min}$ of application nearly complete hair removal on the point of application of the cream was observed. Treatment of Wistar rat with commercia depilatory cream (positive control) (Plate 2 B) shows nearly complete hair removal on the point of application after $20 \mathrm{~min}$ of application. At $40 \mathrm{~min}$ of application, complete hair removal was observed at some parts where the commercial depilatory cream was applied (as indicated by the smooth portion of the rat skin).

Table 2 Effect of Depilatory Ingredients (at Formulation Concentration) on Keratinase Activity for Purified and Crude Keratinases

\begin{tabular}{|c|c|c|c|c|c|c|c|c|c|c|}
\hline \multirow[b]{2}{*}{ Enzyme } & \multirow[b]{2}{*}{ Form } & \multicolumn{8}{|c|}{ Ingredient/ Keratinolytic Activity (U/mL) } & \multirow[b]{2}{*}{ Control } \\
\hline & & $\begin{array}{c}\text { Carbopol } \\
(0.5 \%)\end{array}$ & $\begin{array}{c}\mathrm{CaOH} \\
(0.5 \%)\end{array}$ & $\begin{array}{c}\text { Calcium } \\
\text { Carbonate } \\
(6 \%)\end{array}$ & $\begin{array}{c}\text { Thiourea } \\
(5 \%)\end{array}$ & $\begin{array}{c}\text { TWEEN } 80 \\
(0.02 \%)\end{array}$ & $\begin{array}{c}\text { Liquid } \\
\text { Paraffin } \\
(0.5 \%)\end{array}$ & $\begin{array}{c}\text { EDTA } \\
(0.45 \%)\end{array}$ & $\begin{array}{c}\text { Fragrance } \\
(0.6 \%)\end{array}$ & \\
\hline EZYKer- & Crude & $13.01 \pm 0.84^{\mathrm{c}}$ & $17.31 \pm 0.53^{\mathrm{d}}$ & $10.08 \pm 0.14^{\mathrm{a}}$ & $14.13 \pm 0.29^{\mathrm{c}}$ & $16.12 \pm 1.22^{\mathrm{d}}$ & $12.06 \pm 0.37^{\mathrm{b}}$ & $09.72 \pm 0.47^{\mathrm{a}}$ & $14.13 \pm 0.33^{\mathrm{c}}$ & $19.02 \pm 0.74^{\mathrm{e}}$ \\
\hline 50 & Purified & $14.08 \pm 0.53^{\mathrm{b}}$ & $16.28 \pm 0.86^{\mathrm{c}}$ & $15.03 \pm 1.64^{\mathrm{b}}$ & $18.51 \pm 0.46^{\mathrm{d}}$ & $16.04 \pm 1.73^{\mathrm{c}}$ & $15.69 \pm 0.85^{\mathrm{b}}$ & $08.77 \pm 1.04^{\mathrm{a}}$ & $17.77 \pm 0.52^{\mathrm{d}}$ & $20.64 \pm 0.40^{\mathrm{f}}$ \\
\hline EZYKer- & Crude & $17.21 \pm 0.13^{\mathrm{c}}$ & $15.43 \pm 0.46^{\mathrm{b}}$ & $20.82 \pm 0.87^{\mathrm{de}}$ & $20.26 \pm 0.64^{\mathrm{e}}$ & $15.07 \pm 1.49^{\mathrm{b}}$ & $18.19 \pm 0.73^{\mathrm{d}}$ & $12.32 \pm 1.01^{\mathrm{a}}$ & $15.52 \pm 0.07^{\mathrm{b}}$ & $24.762 \pm 0.91^{\mathrm{f}}$ \\
\hline 51 & Purified & $16.16 \pm 0.47^{\mathrm{b}}$ & $21.24 \pm 0.09^{\mathrm{d}}$ & $22.04 \pm 0.48^{\mathrm{e}}$ & $24.52 \pm 0.06^{\mathrm{f}}$ & $19.48 \pm 0.17^{\mathrm{c}}$ & $22.54 \pm 0.55^{\mathrm{e}}$ & $11.69 \pm 1.87^{\mathrm{a}}$ & $20.61 \pm 0.48^{\mathrm{c}}$ & $26.31 \pm 0.64^{\mathrm{g}}$ \\
\hline EZYKer- & Crude & $12.17 \pm 0.94^{\mathrm{c}}$ & $11.12 \pm 1.36^{\mathrm{b}}$ & $14.01 \pm 0.48^{\mathrm{d}}$ & $14.88 \pm 0.61^{\mathrm{d}}$ & $11.02 \pm 0.73^{\mathrm{b}}$ & $15.51 \pm 1.21^{\mathrm{e}}$ & $8.32 \pm 0.11^{\mathrm{a}}$ & $8.97 \pm 1.20^{\mathrm{a}}$ & $18.407 \pm 0.60^{f}$ \\
\hline 53 & Purified & $10.68 \pm 0.77^{b}$ & $13.16 \pm 0.28^{\mathrm{d}}$ & $12.21 \pm 1.14^{\mathrm{c}}$ & $17.25 \pm 0.04^{f}$ & $12.03 \pm 0.93^{\mathrm{c}}$ & $15.72 \pm 0.56^{\mathrm{e}}$ & $8.29 \pm 1.92^{\mathrm{a}}$ & $12.05 \pm 0.42^{\mathrm{c}}$ & $23.57 \pm 019^{\mathrm{g}}$ \\
\hline
\end{tabular}

Values are in means \pm standard deviation; means with different / similar superscripts along the same row are significantly different / not significantly different from one another at $95 \%$ confidence level

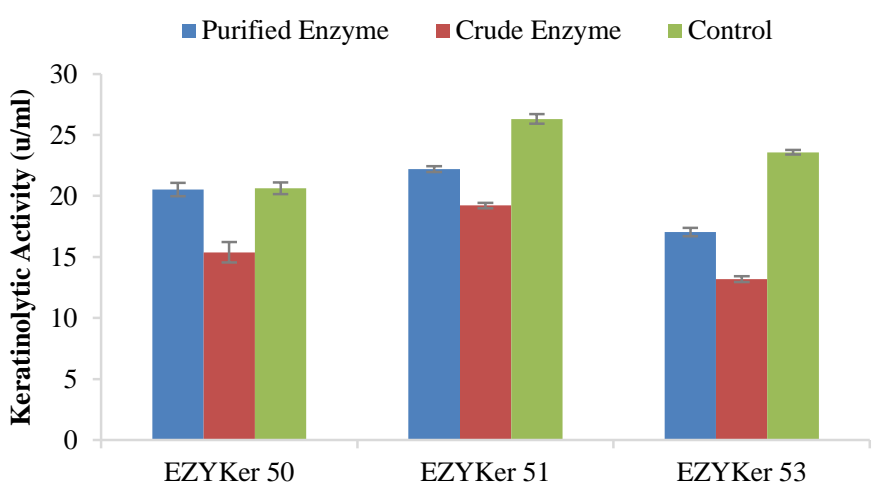

Figure 1 keratinase activity of purified and crude enzyme in the presence of all depilatory ingredients (at formulation concentration)

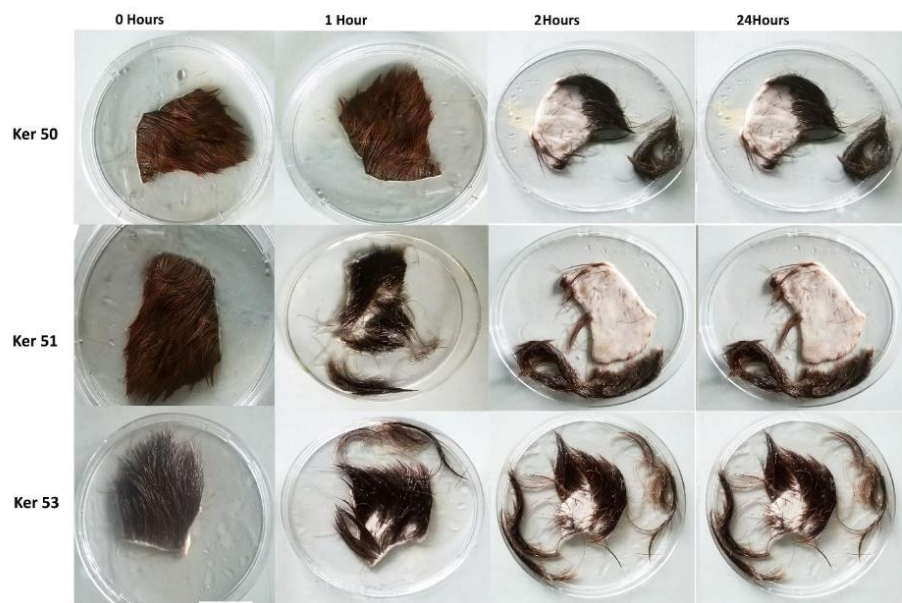

Plate 1 Dehairing function of EZYKer-50, EZYKer-51 and EZYKer-53 with goat hair. untreated white rat
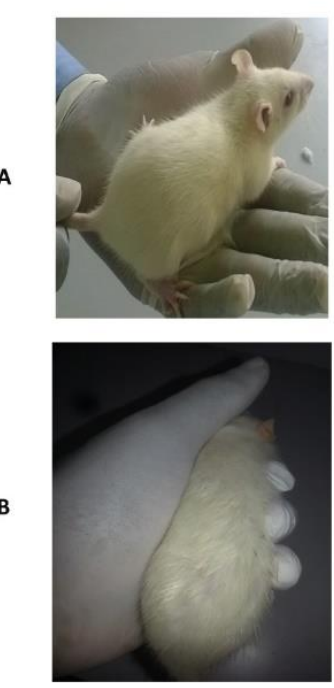

Dehairing of White rat after 20 minutes
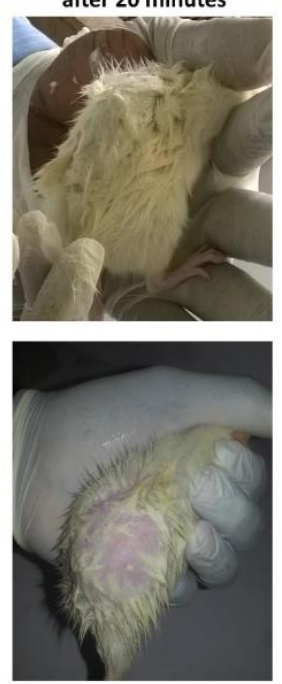

Dehairing of White rat after $\mathbf{4 0}$ minutes
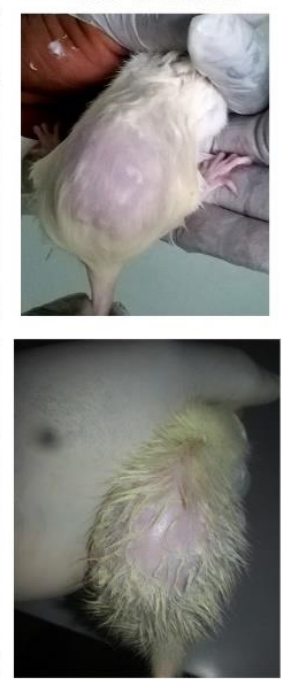

Plate 2 In vivo application of Depilatory Cream on Wistar rat (A) treatment with DEPIKER 51, (B) treatment with commercial depilatory cream

\section{DISCUSSION}

Most Keratinases are known to degrade collagen. Interestingly, EZYKer-50, EZYKer-51 and EZYKer-53 showed no detectable collagenase activities upon reaction with collagen. Cai et al. (2008) and Jaouadi et al. (2011) have also reported bacterial keratinases that lack collagenolytic activities. The keratinases in this study are established as proteases (Dada and Wakil, 2020) but lack the ability to effectively degrade collagen, which is a crucial property for an enzyme intended to be used in skin dehairing. This characteristic suggests the potential utility of the enzymes in the selective removal of hair without causing any damage in the collagen content of skin and hides.

The depilatory components in this study have been selected to give a cosmetic base in the form of a cream. Some components were shown to have individual inhibitory effects on the activity of the enzymes: EDTA had inhibitory effect on 
keratinase activity. This is expected because EDTA is able to chelate most of the divalent cations in the medium, this process of chelation makes the divalent cations unavailable for the keratinase enzyme, and keratinase being mostly a cation-dependent enzyme is inhibited indirectly by EDTA. A similar observation was made by Yassin $\boldsymbol{e t}$ al. (2012) who also reported that the enzyme keratinase was significantly inhibited by the presence of EDTA. Calcium ion was also observed to cause a reduction in keratinase activity. Although the presence of $\mathrm{Ca}^{2+}$ at concentrations of about $10 \mathrm{mM}$ is favourable for keratinase activity (Poopathi et al., 2014), However, it is possible that higher $\mathrm{Ca}^{2+}$ concentration in the form of Calcium carbonate as a depilatory ingredient may have resulted in inhibitory effects on the enzyme.

Despite the inhibitory effects of some of the individual depilatory component on keratinase activity, the enzymes showed significant activities in the presence of the combined cream components. In the combined form of the depilatory ingredients, the resultant keratinase activity $(20.52 \mathrm{U} / \mathrm{mL})$ for EZYKer-50, was higher than the activity of any of the individual components. The resultant activities $(22.20 \mathrm{U} / \mathrm{mL}$ and $17.05 \mathrm{U} / \mathrm{mL})$ for EZYKer-51 and EZYKer-53 was observed to be higher than most of the activities on the individual components, which may have been as a result of the interactions between the components while in combination.

In contrast to chemical depilatories where the active agents; alkaline reducing agents which include salts of thioglycolic acid, have usually an odour of their own, while many others, particularly sulfides, generate the odour of hydrogen sulphide on application (Elumalai et al., 2013), the formulated depilatory cream in this study is free of sulfides, there is therefore no need to use the quantity and type of perfume necessary to mask the foul odour of hydrogen sulfide during depilation, hence, the relatively small amount of light fragrance used in this study

EZYKer-51 was observed to completely remove hair from goat skin within $24 \mathrm{~h}$ The partial removal of hair by EZYKer-50 and EZYKer-53 is likely to be a direct consequence of their different keratinolytic activities which is highest in EZYKer-51 compared to EZYKer-50 and EZYKer-53. This observation confirms that EZYKer-51 alone can accomplish the whole dehairing process. In related finding by Jaouadi et al. (2013), complete hair removal from goat skin was also observed with keratinase from Brevibacillus brevis US575.

The potential of EZYKer-51 in hair removal as active depilatory agent in a depilatory cream formulation is evident in the observation that the hair-degrading ability of the enzyme remained effective even in the presence of all the cream ingredients. This is an interesting observation because there have only been few reports of the incorporation of keratinase as an active ingredient in a depilatory formation. Although, in comparison with commercial depilatories, DEPIKER 51 started depilation slower but had more depilatory effect. The cream base consists of liquid paraffin which serves as emollient and meets the standard of nontoxicity and non-irritancy (Mousumi et al., 2019) to prevent any possible skin irritation and itching that may be experienced by the test objects.

\section{CONCLUSION}

Purified keratinases from Bacillus licheniformis-K51, Bacillus subtilis-K50 and Bacillus sp.-K53; EZYKer-51, EZYKer-50 and EZYKer-53 respectively were significantly ineffective in degrading collagen. EZYKer-51 also demonstrated good dehairing ability in vivo and in vitro and was significantly active in the presence of depilatory ingredients. Overall, the findings provide support for the potential of this enzyme in hair-removal processes.

Acknowledgments: Authors wish to thank the University of Ibadan for providing research facilities for the accomplishment of this work.

\section{REFERENCES}

Ali, M.A., Haj, Ali, A.A., \& Abuuznien, M.H.M. (2018). Improvement of Unhairing in Tanning Process in Sudanese Tanneries. Journal of environmental research, 2, 2-5.

Cai, C., Bing-gan, L., \& Xiao-dong, Z. (2008). Keratinase production and keratin degradation by a mutant strain of Bacillus subtilis. Journal of Zhejiang University SCIENCE B, 9, 60-67. https://dx.doi.org/10.1631\%2Fjzus.B061620

Dada, M.T. \& Wakil, Sherifah. (2020). Production, Purification and Characterisation of Keratinases from Bacillus species Isolated From Poultry Feather Waste. Scientific Research Journal. 08, 83-98. http://dx.doi.org/10.31364/SCIRJ/v8.i4.2020.P0420767.

Elumalai, A., Chinna, M Eswaraiah \&Yoganandam, G.P. (2013). A short communication on formulation and evaluation of depilatories. International Journal of Pharmacy Review and Research, 3(2), 71-73

Feroz, S., Muhammad, N., Ranayake, J., \& Dias, G. (2020). Keratin - Based materials for biomedical applications. Bioactive materials, 5(3), 496-509. https://doi.org/10.1016/j.bioactmat.2020.04.007

Gradisar, H., Kern, S., \& Friedrich, J. (2000). Keratinase of Doratomyces microspores. Applied Microbiology and Biotechnology, 53(2),196-200. https://doi.org/10.1007/s002530050008
Jaouadi, B., Badis, A., Jaouadi, N., \& Bejar, S. (2011). The Bioengineering and Industrial Applications of Bacterial Alkaline Proteases: The Case of SAPB and KERAB. Progress in Molecular and Environmental Bioengineering, 12,445-466. https://doi.org/10.5772/23850

Jaouadi, N.Z., Rekik, H., Badis, A., Trabelsi, S., Belhoul, M., Yahiaoui, A.B. Ben, Aicha. H., Toumi, A., Bejar, S., \& Jaouadi, B. (2013). Biochemical and molecular characterisation of a serine keratinase from Brevibacillus brevis US575 with promising keratin-biodegradation and hide-dehairing activities $\begin{array}{lll}\text { Public Library of Science, } & 2, & 72-726 .\end{array}$ https://doi.org/10.1371/journal.pone.0076722

Kaluzewska, M., Wawrzkiewicz, K., \& Lobarzewski, J. (1991). "Microscopic Examination of keratin substrates subjected to the action of the enzymes of Streptomyces fradiae". International Biodeterioration, 27, 11-26. https://doi.org/10.1016/0265-3036(91)90020-R

Kang, E., Jin, H.S., La, J.W., Sung, J.Y., Park, S.Y., Kim, W.C. \& Lee. D.W. (2019). Identification of keratinases from Fervidobacterium islandicum AW-1 using dynamic gene expression profiling. Microbial Biotechnology, 13, 442457, https://doi.org/10.1111/1751-7915.13493

Lee, Y. J., Rice, R. H. \& Lee, Y. M. (2006). Proteome analysis of human hair shaft: from protein identification to posttranslational modification. Molecular and cellular proteomics, 5, 789-800, https://doi.org/10.1074/mcp.M500278 $\underline{\mathrm{MCP} 200 .}$.

Leighton, T. J., Doi, R. H., \& Warren, R.A.J. (1973). The relationship of serine protease activity to RNA polymerase modification and sporulation in Bacillus subtilis. Journal of Molecular Biology,76, 103-122. https://doi.org/10.1016/0022-2836(73)90083-1

Mousumi, K., Yashu, C., Rahul, M. \& Rakesh K.T. (2019). Basic Fundamentals of Drug Delivery. Advances in Pharmaceutical Product Development and Research, 2, 29-83. https://doi.org/10.1016/B978-0-12-817909-3.00002-9

Munawar, T. (2012). Studies on production of keratinase from different keratin substrates using Bacillus licheniformis strains. International journal of pharmaceutical research and development. 4, 64-68.

Navone, L., Speight, R. (2018). Understanding the dynamics of keratin weakening and hydrolysis by proteases. PLoS ONE 13, e0202608 https://doi.org/10.1371/journal.pone.0202608.

Poopathi, S., Krishnaraj, T., Chinnasamy, M., Lakshmi, V., Kessavane, \& P. Ragul. (2014). Purification and characterization of keratinase from feather degrading bacterium useful for mosquito control - A new report. Tropical biomedicine, 31, 97-109.

Qurat-Ul-Ain \& Iftikhar H.B. (2013). Determination and toxicological effects of metals on human skin by using hair removing creams and lotions by spectroscopic techniques. International Research Journal of Pharmaceutical and Applied Sciences, 3(4), 9-11.

Rogers, G.E., (2004). Hair follicle differentiation and regulation. The International Journal of Developmental Biology, 48, 163-170. https://doi.org/10.1387/ijdb.15272381

Stryer, L., Berg, J. M., \& Tymoczko, J. L. (2002). Biochemistry (5th ed.). San Francisco: ISBN 0-7167-4955-6.

Vidmar, B., \& Vodovnik, M. (2018). Microbial Keratinases: Enzymes with Promising Biotechnological Applications. Food technology and biotechnology, 56(3), 312-328. https://doi.org/10.17113/ftb.56.03.18.5658 Wawrzkiewiez, K., Wolski, T., Lobarzewski, J. (1987). Screening the keratinolytic activity of dermatophytes in vitro. Mycopathologia, 114, 1-8 https://doi.org/10.1007/BF00436684

Yang, F., Zhang, L., \& Rheinstädter, M. (2014). The structure of people's hair. PeerJ, 2(1), 6-19. https://doi.org/10.7717/peerj.619

Yassin, M. E., Amira E., \& Ahmed M.S. (2012). Purification and characterization of a keratinase from the feather-degrading cultures of Aspergillus flavipes African Journal of Biotechnology,11, 2313-2319. https://doi.org/10.5897/AJB11.68

Yutaka, S. \& Masaaki, I. (2015). Human Hair Keratin-Associated Proteins. Journal of Investigative Dermatology, 10(3), 230-233. https://doi.org/10.1111/j.1087-0024.2005.10112.x 